\title{
PENGARUH INPUT DAN PRODUKSI SAWIT TERHADAP PDRB INDONESIA
}

\author{
Reza Juanda ${ }^{* a}$, Intan Mutia ${ }^{\mathrm{b}}$ Ahmad Fauzul Hakim Hasibuan ${ }^{\mathrm{c}}$

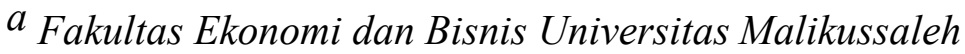 \\ *Corresponding author : juanda.reza@unimal.ac.id
}

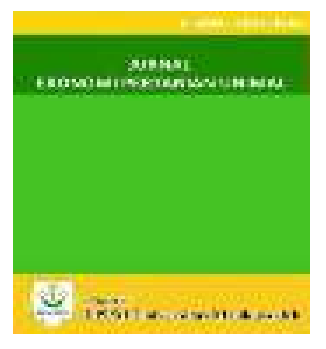

\section{$\underline{\text { ART I CLE IN F ORMATIONABSTRACT }}$}

Keywords:

GRDP, Labor, Land Area, and This study examined the influence of labor, land area, and the the Amount of Production. amount of oil palm production on Gross Regional Domestic Product (GRDP) in Indonesia. This study used the panel data method to determine the effect of independent variables on dependent variables. The data used was secondary data from 2015 to 2018. The results showed that labor and the amount of production significantly influenced GRDP, while the land area had no significant effect on GRDP.

\section{PENDAHULUAN}

Indonesia merupakan negara agraris karena sebagian besar penduduknya bermata pencaharian sebagai petani. Oleh sebab itu pemerintah Indonesia selalu berupaya agar kesejahteraan dan kemakmuran masyarakat terus meningkat. Salah satu upaya pemerintah dalam meningkatkan kesejahteraan dan kemakmuran masyarakat yaitu selalu berupaya meningkatkan pembangunan di berbagai bidang, baik dalam jangka pendek maupun jangka panjang. Industri kelapa sawit merupakan salah satu industri yang sangat tepat dan strategis dalam perekonomian makro, menjadi pusat pertumbuhan baru dan meningkatkan pertumbuhan ekonomi di pedesaan dan diperkotaan.(Permatasari, 2015).

Berikut ini adalah gambaran tenaga kerja,luas lahan, dan jumlah produksi serta PDRB di Indonesia periode tahun 2015 sampai dengan tahun 2018.

\section{Gambar 1.1 Tenaga Kerja, Luas Lahan, Dan Jumlah Produksi}

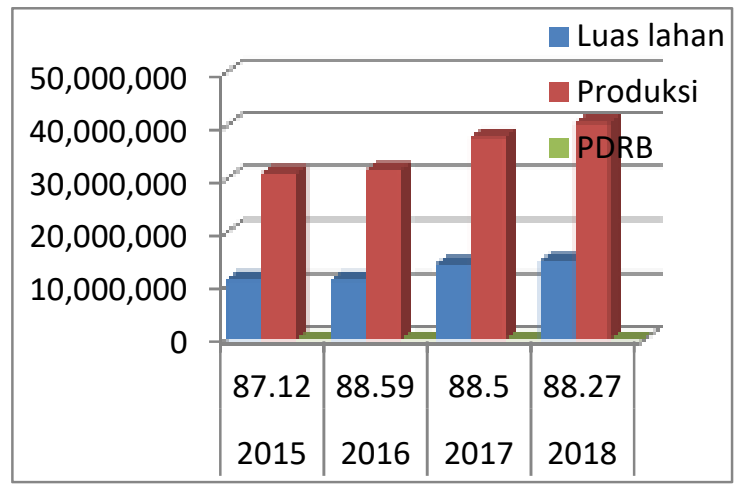

Sumber: BPS 2020

Berdasarkan data yang dikutip dari Badan Pusat Statistik dapat dilihat bahwa PDRB di Indonesia terus mengalami peningkatan selama 4 tahun terakhir yaitu dari tahun 2015 sampai tahun 2018. Pada tahun 2015 PDRB di Indonesia sebesar Rp. 35.162, tahun 2016 Rp. 36.469, tahun 2017 Rp. 37.851 dan pada tahun 2018 PDRB di Indonesia mengalami peningkatan yaitu sebesar Rp. 39.339. Dari data tersebut kita dapat simpulkan bahwa PDRB di Indonesia mengalami peningkatan disetiap tahunnya. Hal tersebut dapat dipengaruhi oleh faktor internal atau faktor eksternal. 
Pada tahun 2015 tenaga kerja di Indonesia mencapai 87,12 jiwa, dan mengalami kenaikan pada tahun 2016 yaitu sebesar 88,59 jiwa, tetapi sayangnya pada tahun 2017 tenaga kerja di Indonesia justru mengalami penurunan yaitu sebesar 88,5 jiwa. Namun tahun 2018 yaitu mengalami kenaikan mencapai 88,27 jiwa.

Pada tahun 2015 Luas lahan kelapa sawit di Indonesia sebesar 11,268 Ha, dan mengalami penurunan pada tahun 2016 sebesar 11,201, dan pada tahun 2017 mengalami kanaikan sebesar 14,048, dan tahun 2018 juga mangalami kenaikan sebesar 14,327 .

Produksi minyak kelapa sawit di Indonesia terus mengalami kenaikan jumlah produksi dari tahun 2015 sampai tahun 2018, tahun 2015 jumlah produksi kelapa sawit sebesar 31,070 ton, dan tahun 2018 40,567 ton.

\section{TINJAUAN PUSTAKA (PDRB)}

Produk Domestik Regional Bruto (PDRB) merupakan indikator yang dipakai untuk mengukur pertumbuhan ekonomi pada tingkat daerah. Sedangkan Produk Domestik Bruto (PDB) merupakan indikator yang dipakai untuk mengukur ekonomi di suatu negara (susanti dkk,2007).

Menurut BPS Provinsi Papua (2000), PDRB atas harga berlaku adalah jumlah nilai produksi atau pendapatan atau pengeluaran yang dinilai sesuai dengan harga yang berlaku pada tahun yang bersangkutan.

\section{Tenaga kerja}

Tenaga kerja merupakan salah satu faktor produksi yang utama dalam perusahaan, sebagai pelaku produksi sampai dihasilkan barang maupun jasa. Tenaga kerja merupakan merupakan orang-orang yang telah dapat memenuhi syarat-syarat yang ditetapkan dalam undang-undang perburuan dinegara yang bersangkutan(Pmdn ,2019)

Tenaga kerja merupakan usaha fisik atau mental yang dikeluarkan karyawan untuk mengolah produk. Mengolah merupakan proses merubah bahan langsung atau baku menjadi barang jadi (Haris Putra, 2018). Tenaga kerja adalah segala kegiatan jasmani maupun rohani atau pikiran manusia yang ditujukan untuk untuk kegiatan produksi(Nasution, 2017)

\section{Luas Lahan}

Istilah lahan digunakan berkaitan dengan permukaan bumi beserta karakteristik- karakteristik yang ada dan penting bagi kehidupan manusia. Secara rinci, istilah lahan atau land dapat dinyatakan sebagai suatu wilayah dipermukaan bumi dan mencakup semua komponen biosfer yang dapat dianggap tetap yang berada diatas atau dibawah wilayah tersebut, termasuk atmosfer, tanah,batuan induk, relief, hidrologi, dan tumbuhan dan hewan. Menurut (Stucchi, 2018)

\section{PRODUKSI}

Menurut (Ariyanto, 2017)mendefinisikan kegiatan produksi dalam perspektif sebagai usaha manusia dalam kegiatan mentransformasikan masukan menjadi keluaran dalam arti sempit. Atau kegiatan menghasilkan barang, baik barang jadi maupun setengah jadi, barang industri, suku cadang, maupun komponenkomponen penunjang.

Menurut(Nawiruddin.M, 2017)mengemukak an bahwa pengertian produksi adalah suatu kegiatan untuk meningkatkan manfaat dengan cara mengkombinasikan faktor-faktor produksi yaitu capital, tenaga kerja, teknologi dan manajemen skill.

\section{KERANGKA KONSEPTUAL Keterkaitan Tenaga Kerja Dengan PDRB}

(Rahman \& Chamelia, 2015) tenaga kerja dalam pembangunan nasional merupakan faktor yang menentukan laju pertumbuhan perekonomian baik dalam kedudukannya sebagai tenaga kerja produktif maupun konsumen. Ketidakseimbangan dalam penyebaran penduduk antar daerah ataupun kota mengakibatkan tidak proporsionalnya penggunaan tenaga kerja secara regional dan sektoral sehingga menghambat laju pertumbuhan perekonomian nasional maupun daerah.

\section{Keterkaitan Luas Lahan Dengan PDRB}

(Nofriadi, 2016) menyatakan bahwa daya dukung lahan merupakan merupakan penggunaan tanah dan data populasi yang sistematis. Dimana seluruh aktifitas manusia dalam mencukupi kebutuhan hidup membutuhkan ruang sehingga ketersediaan lahan berpengaruh besar terhadap aktifitas manusia. Semakin luas lahan yang digunakan maka semakin besar pula produksinya.

\section{Keterkaitan Produksi Dengan PDRB}

Berdasarkan hasil penelitian yang dilakukan oleh Basri (2002) jumlah produksi sangat berpengaruh terhadap peningkatan PDRB di suatu daerah. Karna jumlah produksi merupakan hal yang paling utama dalam melakukan suatu hubungan untuk meningkatkan pendapatan Asli daerah. Tanpa adanya jumlah produksi disuatu daerah maka PDRB 
di suatu daerah tersebut juga tidak akan meningkat. Adapun penjelasannya yaitu:

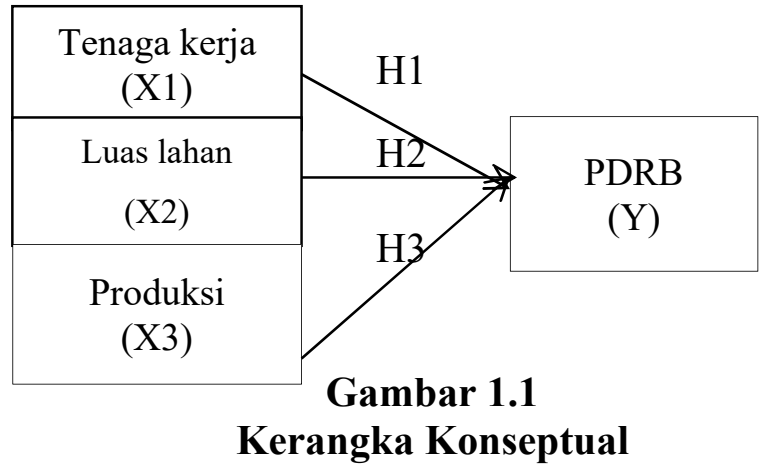

Apakah variabel X1 X2 dan X3 Dalam penelitian ini berpengaruh secara individual terhadap variabel Y.

Untuk melihat pengaruhnya variabel bebas $\mathrm{X} 1, \mathrm{X} 2$, dan X3 secara simultan terhadap variabel Y maka dalam penelitian ini menggunakan uji $\mathrm{F}$.

\section{Hipotesis}

Berdasarkan rumusan masalah, maka hipotesis dalam penelitian ini adalah:

H1 : Diduga tenaga kerja berpengaruh positif dan signifikan terhadap PDRB.

H2 : Diduga Luas lahan berpengaruh secara positif dan signifikan terhadap PDRB.

H3 : Diduga Produksi kelapa sawit berpengaruh secara positif dan signifikan terhadap PDRB.

\section{METODE PENELITIAN}

Analisis data adalah telaah terhadap datadata yang sudah diperoleh kemudian membandingkannya dengan teori-teori yang ada. Metode analisis data sangat mempengaruhi hasil penelitian. Jika metode yang digunakan sesuai dengan obyek penelitian, maka hasilnya akan dapat diterima. Sedangkan jika tidak sesuai, maka penelitian di anggap gagal. Karena itu, ketika melakukan sebuah penelitian, harus mempertimbangkan obyek penelitian dan menentukan metode yang akan dilakukan dalam analisis data.

\section{Objek Dan Lokasi Penelitian}

Objek penelitian yakni tenaga kerja,luas lahan,dan jumlah produksi sebagai variabel bebas dan variabel terikat adalah PDRB. Data yang digunakan dalam penelitian ini adalah dari tahun 2015 sampai dengan tahun 2018. Lokasi penelitian dilakukan di Indonesia.

\section{Jenis dan sumber data}

Penelitian ini menggunakan data sekunder,yang diambil dari periode tahun 2015-
2018, Data-data tersebut diperoleh dari Direktorat Jenderal Perkebunan, dan Badan Pusat Statistik Indonesia.

\section{Metode Pengumpulan Data}

Metode pengumpulan data adalah suatu cara untuk memperoleh kenyataan yang mengungkapkan data-data yang diperlukan dalam suatu penelitian.dalam pengumpulan data yang diperlukan pada penelitian ini menggunakan metode dokumentasi dan studi kepustakaan,yaitu suatu cara untuk memperoleh data atau informasi mengenai hal-hal yang ada kaitannya dengan cara melihat kembali laporan tertulis yang terbaik,baik berupa angka maupun keterangan.

\section{Definisi Operasional variabel}

\section{Produk Domestik Regional Bruto (Y)}

Adalah jumlah nilai tambah barang dan jasa yang timbul dari PDRB sektor pertanian di 25 provinsi yang ada di Indonesia. Dalam tahun tertentu atau periode tertentu, dan dinyatakan dalam pertahun dengan harga konstan dan dinyatakan dalam satuan rupiah. Di peroleh dari BPS di Indonesia.

\section{Tenaga kerja (X1)}

Adalah penduduk yang berada dalam usia produktif di setiap provinsi di Indonesia dan mampu melakukan aktifitas guna menghasilkan barang atau jasa dan dalam perkepala keluarga dan dinyatakan dalam satuan jiwa.

\section{Luas Lahan (X2)}

Luas lahan dalam penelitian ini adalah luas kebun kelapa sawit di setiap provinsi di Indonesia.Variabel bebas (X2) dan menggunakan satuan hektar $(\mathrm{Ha})$.

\section{Produksi(X3)}

Merupakan hasil dari produksi pengelolaan perkebunan kelapa sawit setiap provinsi di Indonesia dan dinyatakan dalam satuan ton.

\section{Metode Analisis Data Panel Analisis Data Panel}

Data panel adalah kombinasi antara data silang tempat (cross section) runtun waktu (time series). Widarjono (2017), menyatakan terdapat beberapa metode yang biasa digunakan dalam mengestimasi model regresi dengan data panel, yaitu pooling least square(CommonEffect), pendekatanefektetap (Fixed Effect), pendekatan efek random (Random Effect).

Metode tersebut digunakan untuk mengetahui bagaimana pengaruh variable terikat dengan variable bebas. Berikut model persamaanya: 
$Y_{i t}=\alpha+\beta_{1} X_{1 i t}+\beta_{2} X_{2 i t}+\beta_{3} X_{3}+\mathrm{e}$

Keterangan :

$\mathrm{Y}=$ Produk Domestik Regional Bruto

$X_{1} \quad=$ Tenaga Kerja

$X_{2} \quad=$ Luas Lahan

$X_{3} \quad=$ Jumlah Produksi

$\beta=$ Koefisien Regresi

$\alpha \quad=$ Konstanta

$e \quad=$ Error Term

i $\quad=$ Banyak nya observasi

$\mathrm{t} \quad=$ Banyaknyawaktu

\section{Pemilihan Model Data Panel}

\section{Chow Test}

Uji Chow digunakan untuk menentukan model mana yang lebih baik digunakan antara Pooled Least Square/Fixed Effect. Dengan ketentuan apabila nilai Chow Statistik ( $\left.\mathrm{F}_{\text {statistik }}\right)$ lebih besar dari $\mathrm{F}_{\text {tabel }}$ maka $\mathrm{H}_{0}$ ditolak $\mathrm{H}_{\mathrm{a}}$ diterima, yang berarti bahwa model yang lebih sesuai dalam menjelaskan permodelan data panel tersebut adalah fixed effect model, begitu pula sebaliknya jika nilai Chow Statistik ( $\left.\mathrm{F}_{\text {statistk }}\right)$ lebih kecil dari $\mathrm{F}_{\text {tabel }}$ maka $\mathrm{H}_{0}$ diterima dan $\mathrm{H}_{\mathrm{a}}$ ditolak.

\section{Hausman Test}

Pengujian ini membandingkan model fixed effect dengan random effect dalam menentukan model yang terbaik untuk digunakan sebagai model regresi data panel (Gujarati,2012).Hipotesis yang dibentuk dalam Hausman test adalah sebagai berikut:

$H_{0}$ : Model Random Effect

$H_{1}$ : Model Fixed Effect

$H_{0}$ ditolak jika $P$-value lebih kecil dari nilai $\alpha$. Sebaliknya, $H_{0}$ diterima jika $P$-value lebih besar dari nilai $\alpha$. Nilai $\alpha$ yang digunakan sebesar $5 \%$.

\section{Uji Asumsi Klasik}

Dalam ekonometrika terdapat uji asumsi klasik dimana setiap penelitian yang dilakukan mesti harus bebas dari uji-uji asumsi klasik tersebut, sehingga penelitian yang akan diteliti baru bisa dilanjutkan.

\section{Uji multikoleneritas}

Multikoleneritas adalah adanya hubungan linear yang signifikan antara beberapa atau semua variabel independen dalam model regresi. Untuk melihat ada tidaknya multikoleneritas dapat dilihat dari koefisien korelasi dari masing-masing variabel bebas lebih besar dari 0,86 berarti terjadinya multikolenaritas. (Henny A.K. Pangkiro, 2016).

\section{Uji Heteroskedasitas}

Heteroskedasitas merupakan keadaan dimana varians dari setiap gangguan tidak konstan.
Sedangkan pengangguran data panel penelitian ini menggunakan cross section, yang menunjukkan bahwa telah terjadi pelanggran homoskedatisitas. Dan untuk mengetahui adanya heteroskedasitas dapat menggunakan uji White Test uji dan Wald Test. ((Pangkiro et al., 2016)

\section{Pengujian Hipotesis}

Pengujian uji statistik dilakukan guna mengetahui apakah perhitungan yang dilakukan signifikan secara statistik atau tidak signifikan. Ketepatan dalam menggunakan regresi dapat di ukur dari goodnes off. Dan dalam analisis regresi terdapat 3 jenis kriteria ketepatan (goodnessof fit ) yaitu : 1) Uji Statistik t, 2) Uji statistik F.

\section{Uji T}

Uji statistik t pada dasarnya menunjukkan seberapa jauh pengaruh variabel independen secara individual dalam menerangkan variasi variabel dependen. Dengan cara membandingkan nilai statistik t, apabila nilai statistik t hitung lebih besar dari t tabel, maka hipotesis alternatif dapat diterima.

\section{Uji F}

Sedangkan uji $f$ menunjukkan semua variabel bebas yang dimasukkan dalam model mempunyai pengaruh secara bersama-sama terhadap variabel terikat dengan cara membandingkan nilai statistik $f$, apabila nilai statistik $\mathrm{F}$ hitung lebih besar dari F tabel, maka hipotesis alternatif dapat diterima.

\section{Koefesien Determinasi $\left(\mathbf{R}^{\mathbf{2}}\right)$}

Koefesien determinasi $\left(\mathrm{R}^{2}\right)$ untuk mengukur seberapa besar kemampuan model dalam menjelaskan variasi variabel dependen (terikat) Nilai dari koefesien determinasi merupakan antara nol dan satu. Jika nilai $\mathrm{R}^{2}$ kecil berarti variabel independen dalam menjelaskan variasi varibel dependen sangat terbatas.

\section{Hasil Penelitian Dan Pembahasan Uji Chow}

Uji Chow merupakan metode untuk menentukan model yang terbaik digunakan antara Pooled Least Square Model. Jika nilai probabilitas F-statistik lebih kecil dari tingkat signifikan $\alpha=5 \%$, maka model terbaik yang digunakan adalah Fixed Effect Model.

Tabel 4.1

\section{Hasil Uji Chow}

\begin{tabular}{|l|l|l|l|}
\hline Effects Test & Statistic & d.f & Pro. \\
\hline Cross-section & 877.248932 & $(24,72)$ & 0.0000 \\
\hline
\end{tabular}




\begin{tabular}{|l|l|l|l|}
\hline F & & & \\
\hline $\begin{array}{l}\text { Cross-section } \\
\text { Chi-square }\end{array}$ & 568.159246 & 24 & 0.0000 \\
\hline
\end{tabular}

Sumber: Hasil Penelitian (data diolah,2020)

Berdasarkan tabel diatas dapat diketahui bahwa nilai probabilitas Cross-Section F sebesar 0.0000 dan nilai tersebut lebih kecil dari tingkat signifikansi $\alpha=5 \%(0.0000<0,05)$, maka model yang digunakan yaitu Fixed Effect Model.

\section{Uji Hausman}

Setelah melakukan uji Chow, dan hasilnya bahwa model yang terbaik yaitu Fixed Effect Model. Maka, langkah selanjutnya yaitu melakukan Uji Hausman. Uji Hausman merupakan metode untuk menentukan model yang terbaik digunakan antara Random Effect Model atau Fixed Effect Model. Jika nilai probabilitas F-statistik lebih kecil dari tingkat signifikansi $\alpha=5 \%$, maka model terbaik yang digunakan adalah Fixed Effect. Sebaiknya, jika nilai probabilitas F-statistik lebih besar dari tingkat signifikansi $\alpha=5 \%$, maka model terbaik yang digunakan yaitu Random Effect Model.

\section{Tabel 4.2}

Hasil Uji Hausman

\begin{tabular}{|l|l|c|c|}
\hline $\begin{array}{l}\text { Test Sum- } \\
\text { mary }\end{array}$ & $\begin{array}{l}\text { Chi- } \\
\text { Sq.Statistic }\end{array}$ & $\begin{array}{l}\text { Chi- } \\
\text { Sq.d.f }\end{array}$ & Prob. \\
\hline $\begin{array}{l}\text { Cross- } \\
\text { section ran- } \\
\text { dom }\end{array}$ & 7.4011504 & 3 & 0.0601 \\
\hline
\end{tabular}

Sumber : Hasil Penelitian (data diolah,2020)

Berdasarkan tabel diatas dapat diketahui bahwa nilai probabilitas Cross-Section random sebesar 0.0601 dan nilai tersebut lebih besar dari tingkat signifikansi $\alpha=5 \%(0.0601>0.05)$, maka model yang baik digunakan yaitu Random Effect model.

Tabel 4.3

Hasil Estimasi Fixed Effect Model

\begin{tabular}{|l|l|l|l|l|}
\hline Variable & $\begin{array}{l}\text { Coeffi- } \\
\text { cient }\end{array}$ & $\begin{array}{l}\text { Std.Erro } \\
\mathrm{r}\end{array}$ & $\begin{array}{l}\mathrm{t}- \\
\text { statistik }\end{array}$ & Prob. \\
\hline $\mathrm{C}$ & 9.745532 & 0.11487 & 84.8393 & 0.0000 \\
\hline LOGTK & 0.018108 & 0.00705 & 2.56565 & 0.0124 \\
\hline LOGLHN & 0.001370 & 0.00677 & 0.20227 & 0.8403 \\
\hline LOGPDS & 0.009824 & 0.00511 & 1.92133 & 0.0586 \\
\hline
\end{tabular}

Sumber : Hasil Penelitian (data diolah,2020)

Tabel 4.4

Hasil Estimasi Random Effect Model

\begin{tabular}{|c|c|c|c|c|}
\hline Variable & $\begin{array}{c}\text { Coeffi- } \\
\text { cient }\end{array}$ & Std.Error & t-statistik & Prob. \\
\hline C & 9.730295 & 0.20152 & 48.28295 & 0.0000 \\
\hline
\end{tabular}

\begin{tabular}{|c|c|c|c|c|}
\hline LOGTK & 0.017988 & 0.00705 & 2.549583 & 0.0124 \\
\hline LOGLHN & 0.001976 & 0.00676 & 0.292169 & 0.7708 \\
\hline LOGPDS & 0.010550 & 0.00510 & 2.066966 & 0.0414 \\
\hline
\end{tabular}

Sumber : hasil penelitian (data diolah,2020)

Random Effect Model merupakan model data panel yang digunakan didalam penelitian ini dan dapat dijelaskan melalui persamaan sebagai berikut

$\mathrm{PDRB}=9.730295+0.017988 \mathrm{TK}+0.001976 \mathrm{LHN}+0.0$ 10550PDS

PDRB : Produk Domestik Regional Bruto

TK : Tenaga Kerja

LHN : Luas Lahan

PDS : Produksi

Dari persamaan diatas menunjukkan bahwa nilai konstanta sebesar 9.730295, artinya apabila variabel tenaga kerja, luas lahan,dan jumlah produksi di anggap konstan $=0$, maka nilai PDRB meningkat sebesar 9.730295. Nilai koefesien dari variabel Tenaga Kerja sebesar 0.017988 , artinya apabila tenaga kerja meningkat $1 \%$ maka akan meningkatkan PDRB sebesar 0.017988. Dan jika nilai koefesien variabel Luas lahan sebesar 0.001976 , artinya apabila luas lahan meningkat $1 \%$ maka akan meningkatkan PDRB sebesar 0.001976. Selanjutnya nilai koefesien variabel Produksi sebesar 0.010550, artinya apabila jumlah produksi meningkat sebesar 1\% maka akan meningkatkan PDRB sebesar 0.010550 .

\section{Pengujian Hipotesis \\ Uji Parsial (uji t)}

Uji t-Statistik dilakukan untuk mengetahui apakah terdapat pengaruh independen secara individual (parsial) terhadap dependen. Dengan ketentuan Uji t yaitu melihat nilai tabel dengan nilai $t_{\text {statistik. }}$ Jika nilai $t_{\text {statistik }}>t_{\text {tabel }}$ dengan probabilitas dibawah $(<0.05)$, maka independen berpengaruh terhadap dependen. Berikut hasil dari penelitian ini yang di Uji secara parsial.

Tabel 4.5

Hasil Uji T-statistik

\begin{tabular}{|l|l|l|l|l|}
\hline Variabel & T- & T-tabel & Probability & Keterangan \\
Independen & statistk & & & \\
Kenaga & 2.565653 & 1.72074 & 0.0124 & Signifikan \\
\cline { 1 - 1 } Luas lahan & 0.202276 & & 0.8403 & Tidak sig- \\
& & & & nifikan \\
\hline
\end{tabular}




\begin{tabular}{|l|l|l|l|l|}
\hline Produksi & 1.921332 & & 0.0586 & Signifikan \\
\hline
\end{tabular}

Berdasarkan hasil uji parsial pada 4.10 terlihat bahwa Tenaga Kerja memiliki nila it $=2.565653>1,72074$ dengan Probability $(0.0124<$ 0.05). maka dapat disimpulkan bahwa tenaga kerja berpengaruh positif dan signifikan terhadap PDRB di 6interlan tahun 2015-2018.

Variabel luas lahan memiliki nilai $t_{\text {statistiks }}$ sebesar $0.202276<1,72074$ dengan Probability 0.8403> 0.05. maka dapat disimpulkan bahwa luas lahan berpengaruh secara positif dan tidak signifikan terhadap PDRB di tahun 2015-2018.

Variabel produksi memeliki nilai $t_{\text {statistik }}$ sebesar 1.921332>1,72074 dengan Probability 0.0586> 0.05. maka dapat disimpulkan bahwa produksi berpengaruh secara positif dan signifikan terhadap PDRB di Indonesia tahun 2015-2018.

\section{Uji F}

Uji F merupakan uji simultan yang dilakukan untuk mengetahui apakah independen yaitu luas lahan, investasi dan tenaga kerja secara serentak atau bersama-sama mempengaruhi dependen yaitu PDRB di Indonesia

Tabel 4.6

\section{Uji F (simultan)}

\begin{tabular}{|l|l|l|l|}
\hline F statistik & F tabel & Probability & Keterangan \\
\hline 981.7558 & 2,70 & 0.017353 & Signifikan \\
\hline
\end{tabular}

Berdasarkan tabel diatas telihat bahwa $\mathrm{F}$ Statistik $>$ F Tabel $(981.7558>3,07)$ dengan probilitiy sebesar $(0.017353<0.05)$ maka dapat disimpulkan tolak Ho terima $\mathrm{H}_{1}$ yang artinya secara bersama-sama tenaga kerja, luas lahan dan produksi berpengaruh positif dan signifikan terhadap PDRB.

\section{PENUTUP}

\section{Kesimpulan}

Berdasarkan hasil analisis dari pembahasan maka dapat diberi kesimpulan sebagai berikut :

1. Variabel Tenaga kerja yang digunakan dalam penelitian ini berpengaruh positif dan signifikan terhadap PDRB dikarnakan semakin banyak angkatan kerja, berarti semakin produktif tenga kerja. Karena semakin besar angkatan kerja akan meningkatankan partisipasi tenaga kerja yang mampu meningkatkan PDRB.

2. Variabel Luas lahan yang digunakan dalam penelitian ini berpengaruh positif dan tidak signifikan terhadap PDRB karena saat ini banyak terjadi fenomena alih fungsi lahan adalah bagian dari perjalanan transformasi dari stuktur ekonomi nasional. Pertumbuhan ekonomi dan penduduk yang memusat diwilayah perkotaan menuntut ruang lebih luas kearah luar kota bagi berbagai aktivitas ekonomi dan untuk pemukiman. Sebagai akibatnya, wilayah yang sebagian besar lahan pertanian beralih fungsi (konversi) menjadi lahan perkotaan.

3. Variabel Produksi yang digunakan dalam penelitian ini berpengaruh positif dan signifikan terhadap PDRB di Indonesia karena jumlah produksi merupakan hal yang paling utama dalam melakukan suatu hubungan untuk meningkatkan pendapatan Asli daerah. Tanpa adanya jumlah produksi disuatu daerah maka PDRB di suatu daerah tersebut juga tidak akan meningkat. Hal ini sesuai dengan teori yang menyatakan bahwa, kenaikan jumlah produksi akibat bertambahnya lahan maka akan menyebabkan kenaikan produksi. Dan pada akhirnya akan menyebabkan kenaikan pada PDRB.

\section{Saran}

Dari hasil penelitian yang telah dilakukan maka penulis dapat beberapa saran atau masukan yaitu sebagai berikut :

1. Saran bagi pemerintahan Indonesia agar memberdayakan sumber daya alam dengan selefektif mungkin. Serta menggali sumber daya yang dimiliki masing-masing wilayah setiap Provinsi. Sehingga wilayah tersebut dapat membangun ekonomi sesuai potensi yang dimiliki. Sehingga apabila masingmasing provinsi sudah adanya kegiatan ekonomi sesuai dengan potensi yang ada maka akan mudah dalam membuat hubungan ekonomi antar wilayah provinsi. Sehingga akan mengurangi ketergantungan wilayah Provinsi terhadap Indonesia,

2. Dalam melakukan kebijakan penggunaan lahan, pemerintah perlu memperhatikan sektor pertanian sebagai sektor yang dominan.

3. Saran bagi mahasiswa Ekonomi Pembangunan Universitas Malikussaleh lebih tertarik untuk meneliti permasalahanpermasalahan di Indonesia, sehingga dapat memberikan berbagai solusi dalam permasalahan yang dihadapi di Indonesia. Terlebih dengan produksi minyak kelapa sawit di Indonesia.

4. Perlu dilakukan penelitian lebih lanjut dengan memasukkan Variabel yang lebih banyak. 
Ariyanto, B. (2017). Pengaruh Investasi Kelapa Sawit Dan Tenaga Kerja Terhadap PDRB pada Sub Sektor Perkebunan di Kabupaten Kutai Timur. Forum Ekonomi, 19(1), 42. https://doi.org/10.29264/jfor.v19i1.2112

Bruto, R., Pertanian, S., Kota, D. I., Katiandagho, T. M., \& Olfie, B. (2016). Sumber : BPS Kota Tomohon dapat dipindah . b . Luas lahan pada suatu wilayah hampir tidak berubah. Perubahan dapat terjadi apabila ada reklamasi perairan menjadi dataran. berdimensi kompleks, yaitu ekonomi ,. 12, 13-28.

Contents, T. O. F. (2010). Journal of Development Economics Author Information Pack. 1-9.

Damayanti, L. (2017). Analisis Dampak Aglomerasi Terhadap Ketimpangan Regional Pulau Jawa. Jurnal Ilmiah Mahasiswa FEB Universitas Brawijaya.

Direktorat Jenderal Perkebunan. (2020). Palm Oil Area by Province in Indonesia , 2013-2020. Luas Areal Kelapa Sawit, 1, 1.

Harini, R. (2013). Agricultural Land Conversion: Determinants and Impact for Food Sufficiency in Sleman Regency. Indonesian Journal of Geography,

https://doi.org/10.22146/indo.j.geog,2394

Haris Putra, F., Mustika Ani, H., \& Hartanto, W. (2018). Kontribusi Sektor Pertanian Terhadap Pdrb Kabupaten Jember Tahun 2012-2016. JURNAL PENDIDIKAN EKONOMI: Jurnal Ilmiah Ilmu Pendidikan, Ilmu Ekonomi Dan Ilmu Sosial, 12(1), 71. https://doi.org/10.19184/jpe.v12i1.7589

Junisa, D., Arimbi, D. A. S., Situmorang, E., Erviani, E., Handayani, F., \& Siagian, J. (2015). Analisis Ketimpangan Pembangunan Antar Daerah Sumatera Utara Bagian Timur. QE Journal, 04(04), 236-249. https:/qejournal.github.io/publications/QEJ-Vol-04No-04-Article-03-Dewi-Junisa-etal.pdf

Kartikasari, D. (2017). International Journal of Economics and Financial Issues The Effect of Export, Import and Investment to Economic Growth of Riau Islands Indonesia. International Journal of Economics and Financial Issues, 7(4), 663-667. http:www.econjournals.com

Lubis, M. F., \& Lubis, I. (2018). Analisis Produksi Kelapa Sawit (Elaeis Guineensis Jacq.) Di Kebun Buatan, Kabupaten Pelalawan, Riau. Buletin Agrohorti, 6(2), 281-286. https://doi.org/10.29244/agrob.v6i2.18945

Maharani, D. (2016). Analisis Pengaruh Investasi Dan Tenaga Kerja Terhadap Produk Domestik
Regional Bruto (PDRB) Di Sumatera Utara. Intiqad: Jurnal Agama Dan Pendidikan Islam, $8(2)$, 32-46.

https://doi.org/10.30596/intiqad.v8i2.725

Maisaroh, M., \& Risyanto, H. (2018). Pengaruh Investasi, Pengeluaran Pemerintah Dan Tenaga Kerja Terhadap Pdrb Provinsi Banten. EkBis: Jurnal Ekonomi Dan Bisnis, 1(2), 206. https://doi.org/10.14421/ekbis.2017.1.2.1049

Mara, A., \& Fitri, Y. (2013). Dampak Perkebunan Kelapa Sawit Rakyat Terhadap Pendapatan Wilayah Desa ( Pdrb ) Di Provinsi Jambi Smallholders Oil Palm Estate Impact Against Village Gross Regional Domestic Product ( Grdp ) in Jambi. Agrisep, 13(1), 101-110.

Nasution, H. S. (2017). Analisis Faktor - Faktor Yang Mempengaruhi Pertumbuhan Produk Domestik Regional Bruto Era Desentralisasi Fiskal Di Propinsi Banten Periode 2001:12009:4. Media Ekonomi, 18(2), 29. https://doi.org/10.25105/me.v18i2.2250

Nawiruddin.M. (2017). Dampak keberadaan perkebunan kelapa sawit dalam peningkatan pendapatan masyarakat di kecamatan long kali kabupaten paser. Jurnal Ilmu Pemerintahan, $5(1), 1-14$.

Nofriadi. (2016). Analisis Faktor-Faktor yang Mempengaruhi Produksi Karet di Kecamatan Mestong Kabupaten Muaro Jambi (Studi kasus Desa Muaro Sebapo). E-Jurnal Ekonomi Sumberdaya Dan Lingkungan, 5(1), 1-12. https://online-

journal.unja.ac.id/JSEL/article/view/3923/2854

Pangkiro, H. A. K., Rotinsulu, D. C., Patrick, D., Jurusan, W., Pembangunan, E., Ekonomi, F., \& Bisnis, D. (2016). Analisis Pertumbuhan Ekonomi Dan Kemiskinan Terhadap Tingkat Ketimpangan Di Provinsi Sulawesi Utara Analysis of Growth Economic and Poverty on the Level of Inequality in North Sulawesi. Jurnal Berkala Ilmiah Efisiensi, 16(01), 339351.

Selatan, S. (2019). Pengaruh Produktivitas Perkebunan Kelapa Sawit terhadap Produk Domestik Regional Bruto serta Dampaknya pada Pengentasan Kemiskinan di Provinsi Sumatera Utara Oleh: Email: masnilamhasibuan@yahoo.co.id_Fakultas Ekonomi, Universitas Graha Nusantara, Pada. 21.

Sumowono, K., \& Semarang, K. (2013). Economics Development Analysis Journal. 2(4), 446-455.

permatasari, anisa. (2015). Analisis Peranan Sektor Pertanian Dalam Perekonomian Di Kabupaten Grobogan. In skripsi (p. 99). 
Produksi Kelapa Sawit Menurut Provinsi di Indonesia , 2016-2020 Palm Oil Production by Province in Indonesia , 2016-2020. (2020). 2020, 2020.

Purba, J. H. V, \& Sipayung, T. (2017). Perkebunan Kelapa Sawit Indonesia dalam Perspektif Pembangunan Berkelanjutan. Jurnal IlmuIlmu Sosial Indonesia, 43(1), 81-94. http://jmi.ipsk.lipi.go.id/index.php/jmiipsk/arti cle/view/717/521

Rahman (2015). Faktor - Faktor Yang Mempengaruhi Pdrb Kabupaten / Kota Jawa Tengah Tahun 2008-2012. Jejak, 8(1), 88-99. https://doi.org/10.15294/jejak.v8i1.3857

Sirdon (2013). Pengaruh Tenaga kerja, jumlah produksi dan luas lahan terhadap PDRB sektor pertanian di Kabupaten Sumatera Barat. Jurnal Ekonomi Pembangunan, 02(02), $1-12$.

Sitorus (2019). Pengaruh Luas Lahan dan Jumlah Produksi Kelapa Sawit Terhadap Produk Domestik Regional Bruto (PDRB) Sub Sektor Perkebunan Di Kabupaten Asahan. In Sripksi (Sumatera U, p. 156). Universitas Islam Negeri.

Statistik, B. P. (2019). Luas Lahan Dalam Angka 2015-2019. Badan Pusat Statisktik Indonesia.

Statistik, B. P. (2020). Tenaga Kerja dalam Angka Tahun 2015-2019.

Stucchi, \& Rossi, M. A. (2018). The Impact of Export Restrictions on Production: A Synthetic Control Approach. Economía Journal, Volume 18(Spring 2018), 147-173. https://ideas.repec.org/a/col/000425/016335.ht $\mathrm{ml}$

Tambunan (2016). Analisis Pengaruh Investasi, Operasi Moneter dan ZIS terhadap Pertumbuhan Ekonomi Indonesia. 1(1), 1173. 